\title{
POWER OF FEDERAL COURTS TO STAY STATE CRIMINAL PROCEEDINGS*
}

FEDERAL courts are reluctant to interfere with state criminal law administration. Under the doctrine of comity, ${ }^{1}$ they defer to the states at all stages of the enforcement process. Thus, unless there is a showing of exceptional circumstances, federal courts usually (1) decline to enjoin threatened criminal prosecutions under allegedly unconstitutional state laws; (2) refuse to stay pending state criminal proceedings; ${ }^{3}$ and (3) deny federal habeas corpus to state prisoners until they have exhausted direct and collateral state remedies. ${ }^{4}$

A recent third circuit decision, Cooper v. Hutchinson, ${ }^{5}$ in effect reverses this policy in applying the Federal Civil Rights Act $^{6}$ to state criminal pro-

*Cooper v. Hutchinson, 184 F. 2d 119 (3d Cir. 1950).

1. For the history of this doctrine, see Warren, Federal and State Court Interference, 43 HaRv. L. Rev. 345 (1930). See also Note, 54 HaRv. L. Rev. 1379 (1941).

2. See, e.g., Douglas v. City of Jeanette, 319 U.S. 157 (1943) (municipal ordinance allegedly denying free speech; injunction denied). See note 30 infra.

3. See, e.g., Cline v. Frink Dairy Co., 274 U.S. 445, 453 (1927) (enjoining threatened prosecutions under Colorado antitrust law but refusing to stay proceeding already pending in state court). See notes 30 and 33 infra.

4. Ex parte Hawk, 321 U.S. 114 (1944). The Hazek doctrine was codified in $\$ 2254$ of the new Judicial Code: "An application for a writ of habeas corpus in behalf of a person in custody pursuant to the judgment of a State court shall not be granted unless it appears that the applicant has exhausted the remedies available in the courts of the State . . . " 28 U.S.C. \$2254 (1948). "Available remedies" have been recently interpreted to include a petition for certiorari to the United States Supreme Court. Darr v. Burford, 339 U.S. 200 (1950), 50 CoL. L. Rev. 856.

The Supreme Court has announced that the exhaustion requirement "presupposes that some adequate state remedy exists ...." Young v. Ragen, 337 U.S. 235, 239 (1949). But many commentators have criticized the exhaustion rule as being too rigidly applied. See, e.g., Note, The Judicial Obstacle Course, 29 NEB. L. REv. 445 (1950). For a contrary view, see Parker, Limiting the Abuse of Habeas Corpus, 8 F.R.D. 171 (1949).

5. 184 F. 2d 119 (3d Cir. 1950).

6. "Every person who, under color of any statute, ordinance, regulation, custom or usage, of any State or Territory, subjects or causes to be subjected, any . . person . . . to the deprivation of any rights, privileges or immunities secured by the Constitution and laws, shall be liable to the party injured in an action at law, suit in equity, or other proper proceeding for redress." Rev. STat. \& 1979 (1879), 8 U.S.C. \& 43 (1946). The section was originally part of the Ku Klux Klan Act of 1871, 17 Stat. 13 (1871). Section 1343 of Title 28 vests the district courts with original jurisdiction over civil actions to redress deprivations under $\$ 43.62$ STAT. 932 (1948), 28 U.S.C. $\S 1343$ (1948). No jurisdictional amount is necessary in actions under this statute. Hague v. C.I.O., 307 U.S. 496, 513 (1939). For the legislative history of $\$ 43$, see Cong. Globe, 42d Cong. 1st Sess., Part 1, Report on H.R. No. 320, p. 317, and debate pp. 317, 329, 335, 351, 361, 376, 393, 408, 421, 436, 463, 475, 489, 508, Part 2, Appendix, pp. 86, 113, 209, 216, 217 (1871).

The act was largely neglected for many years after its passage. See Konvitz, THE Constitution and Civil Rigitss 8-47 (1947). But in the past decade civil rights actions 
ceedings. Three New York counsel had secured a reversal by the New Jersey Supreme Court of Cooper's conviction for murder. ${ }^{T}$ On retrial, the trial court admitted the out-of-state counsel pro hac vice ${ }^{8}$ to assist in the defense. But after hearing preliminary motions, the trial judge summarily dismissed the lawyers. Cooper immediately brought suit in the federal district court under the Civil Rights Act, alleging that the trial judge, acting under color of law, had deprived him of his constitutional right to counsel of his choice. He sought to enjoin the trial judge from proceeding further without first reinstating the lawyers.

The district court sustained a motion to dismiss on the ground that the Civil Rights Act did not authorize it to enjoin the state trial. ${ }^{\circ}$ Reversing, the third circuit held that the summary removal of counsel deprived Cooper of a constitutional right. ${ }^{10}$ However, in view of the strong federal policy against interference with state proceedings, equitable discretion required withholding injunctive relief until it appeared that state courts would not correct the error. ${ }^{11}$ The court assumed that the applicable New Jersey statute would

have succeeded with growing frequency. See, e.g., Westminster School District v. Mendez, 161 F. 2d 774 (9th Cir. 1947) (enjoining segregation of Mexican school children); Sellers v. Johnson, 163 F. $2 d 877$ (8th Cir. 1947) (enjoining municipal officials from interfering with free speech and assembly). For a recent discussion of the Civil Rights Act, see Fraenkel, The Function of the Lower Federal Courts as Protectors of Civil Liberties, 13 LaW \& Contemr. Prob. 132, 137-41 (1948).

7. State v. Cooper, 2 N.J. 540, 67 A. $2 d 298$ (1949). This was the notorious case of the "Trenton Six." See N.Y. Times, December 27, 1949, p. 9, col. 3; March 24, 1949, p. 56 , col. 2; May 17, 1949, p. 18, col. 2; May 24, 1949, p. 6, col. 4; July 1, 1949, p. 1, col. 2. For developments subsequent to the reversal, see N.Y. Times, July 2,1949 , p. 6 , col. 6 ; id., p. 14, col. 3 ; July 20, 1949, p. 7, col. 1 ; July 21, 1949, p. 20, col. 1 ; July 30, 1949, p. 13, col. 6; August 5, 1949, p. 8, col. 1; November 22, 1949, p. 33, col. 3; December 14, 1949 , p. 34 , col. 4 ; December 17, 1949, p. 1, col. 6 .

8. "For the particular case." See Rules Governing the Courts of New Jersey $1: 8-10$ (b).

The Supreme Court of New Jersey had previously admitted these counsel to argue the appeal from the first conviction. Cooper v. Hutchinson, 184 F. 2d 119, 121 (3d Cir. 1950).

9. Cooper v. Hutchinson, 88 F. Supp. 774 (D. N.J. 1950).

10. Cooper v. Hutchinson, 184 F.2d 119, 123 (3d Cir. 1950). Since the Cooper case was a capital case, the Fourteenth Amendment guaranteed the defendants a federal right to counsel. Powell v. Alabama, 287 U.S. 45 (1932). In the federal courts, under the Sixth Amendment, this right has been held to include the right to out-of-state counsel of defendant's choosing. United States v. Bergamo, 154 F.2d 31 (3d Cir. 1946). It is not settled whether the Fourteenth Amendment, even in capital cases, goes so far. The third circuit declined to decide this question in the instant case. Instead, the court held that once counsel had been admitted to appear for the defendant, the Fourteenth Amendment prohibited his dismissal without cause. See note 14 infra. See Note, 51 CoL. L. Rev. 127 (1951), suggesting that, to protect the accused while preserving the interests of the judiciary, the trial court either grant defendants' requests for non-resident counsel or state in the record his reasons for refusal.

11. Cooper v. Hutchinson, 184 F. 2d 119, 124 (3d Cir. 1950). The court was impressed by Supreme Court holdings that federal courts should not enjoin the enforcement of state 
permit interlocutory appeal.12 It therefore remanded with directions to retain jurisdiction pending such appeal. ${ }^{13}$ The result was to achieve the effect of an injunction without granting one; the threat of injunction effectively stayed the state proceedings until the constitutional defect could somehow be eradicated. ${ }^{14}$

In order to reach this result, the court first had to hurdle a statutory codification of the comity rule. Section 2283 of the Judicial Code provides broadly that a federal court "may not grant an injunction to stay proceedings in a State court." Three exceptions are specified: where there is express authorization by Act of Congress; where the injunction is necessary in aid of the court's jurisdiction; or where the injunction is needed to protect or effectuate the court's judgments. ${ }^{15}$ The third circuit chose the first exception

statutes until the state first construes them. E.g., A.F. of L. v. Watson, 327 U.S. 582 (1946), discussed in note 30 infra; Railroad Commission v. Pullman Co., 312 U. S. 496 (1941) (discriminatory regulatory order not yet reviewed by state courts), noted in 50 Yale L. J. 1272 (1941).

12. Cooper v. Hutchinson, 184 F. $2 \mathrm{~d} \mathrm{119,123-4} \mathrm{(3d} \mathrm{Cir.} \mathrm{1950).} \mathrm{The} \mathrm{state} \mathrm{statute} \mathrm{provides}$ that "[n]o appeal shall be taken in any criminal case until final judgment has been rendered." N.J. Stat. Ann. § 2:195A-3 (Cum. Supp. 1949). But "[a]ppeals may be taken to ... [the Superior Court] from orders or judgments, whether or not interlocutory ... (a) when necessary to preserve and maintain the res or status quo pending final judgment and prevent irreparable injury or mischief." RULEs GoverNING THE CouRTs of NEW JERSEY 1:2-2. Neither rule has as yet been applied to allow interlocutory appeals in criminal proceedings.

13. The procedure of remanding a case to the district court with instructions to retain jurisdiction pending termination of state proceedings was first adopted in Railroad Commission v. Pullman Co., 312 U.S. 496 (1941), supra note 11. Until the Cooper case, it had been employed only to obtain a state court construction of statutes or regulatory orders sought to be enjoined as unconstitutional. See, e.g., A.F. of L. v. Watson, supra note 11; Chicago v. Fieldcrest Dairies, Inc., 316 U.S. 168 (1942).

14. Unless some interlocutory state remedy proved to be available, the district court presumably was to grant an immediate hearing on the issue of cause for the dismissal of the attorneys. See Cooper v. Hutchinson, 184 F.2d 119, 125 (3d Cir. 1950). On the other hand, if the state courts, after a hearing, refused to reinstate counsel, it is not clear whether the district court was to review their determination. The court's language implies that what constitutes cause for dismissal is a constitutional question to be ruled on by the federal courts: "... the representation was granted and may not, without cause, be taken away." Id. at 123 (emphasis added).

In fact, Cooper did not attempt an interlocutory appeal. Instead, the Mercer County Court issued an order requiring the out-of-state lawyers to show cause why they should not be excluded from the defense. Communication to the YaLE Law Journal from George Gildea, author of Amici Curiae Brief, October 25, 1950, in Yale Law Library. Before the hearing was had, the lawyers withdrew. N.Y. Times, November 9, 1950, p. 51, col. 6; November 30, 1950, p. 28, col. 6 . The case was thereby mooted.

15. 28 U.S.C. $\$ 2283$ (1948). The statute merely states the rule of comity and does not go to the jurisdiction of the federal court. See Smith v. Apple, 264 U.S. 274, 278 (1924). The predecessor of $\S 2283$ had been on the statute books since 1793. 1 Star. 333 (1793), as amended 28 U.S.C. $\$ 379$ (1946) ("The writ of injunction shall not be granted by any court of the United States to stay proceedings in any court of a State" [except, by later 
as the basis for ruling that Section 2283 did not bar injunctive relief. Since the Civil Rights Act permits "suits in equity" by the aggrieved party, the court reasoned, it constitutes an express statutory authorization. ${ }^{16}$ Presumably the court thought that by subjecting to liability in equity "every person" who acts under color of law to deprive another of constitutional rights, the Civil Rights Act contemplates use of the traditional equitable remedy of injunction against state court judges. ${ }^{17}$

However, this particular rationale seems unjustified when the Civil Rights Act is compared with other statutes coming within the Congressional authorization exception. The statutes fall into two groups. On the one hand are the acts authorizing removal, ${ }^{18}$ habeas corpus, ${ }^{19}$ and interpleader. ${ }^{20}$ These procedural devices can function only if federal courts can stay proceedings in state courts. Thus removal would be senseless if the removed action continued in the state court, and habeas corpus might be futile if the state proceedings progressed to judgment and execution. Similarly, since the purpose of the Interpleader Act is to protect against multiple litigation of a single liability, ${ }^{21}$

amendment, in bankruptcy cases]). During its long history, former $\$ 379$ was riddled with exceptions by judicial construction. See Warren, supra note 1.

The third exception to $\S 2283$, authorizing stays of state proceedings when necessary to protect or effectuate the judgments of a federal court, is not relevant to the problem of enjoining state criminal proceedings. This exception was merely a statutory overruling of Toucey v. New York Life Insurance Co., 314 U.S. 118 (1941), which held that former $\$ 379$ prohibited federal courts from enjoining relitigation in state courts of matters already adjudicated in the federal court. See 28 U.S.C. $\$ 2283$, Reviser's Note (1948).

16. Cooper v. Hutchinson, 184 F. 2d 119, 124 (3d Cir. 1950). Two early cases held that the Civil Rights Act, 8 U.S.C. $\S 43$ (1946) was merely declaratory and did not affect former § 379. Aultman \& Taylor Co. v. Brumfield, 102 Fed. 7 (C.C. N.D. Ohio 1900), appeal dismissed, 46 L.Ed. 1265 (1902); Hemsley v. Myers, 45 Fed. 283, 289 (C.C. D. Kan. 1891). Contra: Tuchman v. Welch, 42 Fed. 548, 558 (C.C. D. Kan. 1890).

17. Although Congress assumed that the Civil Rights Act would subject state judges to liability in damages for action taken in their official capacity, apparently the possibility of enjoining judges under the Act did not occur to the legislators. For the legislative history of $\S 43$, see note 6 supra. See also Note, 46 CoL. L. REv. 614, 618 (1946).

18. 28 U.S.C. $\& 1446$ (e) (1948) provides that when a case has been removed to the federal court ". . . the State court shall proceed no further unless and until the case is remanded." See Madisonville Traction Co. v. Saint Bernard Mining Co., 196 U.S. 239, 245 (1905) (former $\$ 379$ did not forbid enjoining party from taking further steps in state court).

19. 28 U.S.C. $\$ 2251$ (1948) ("... [a federal judge] before whom a habeas corpus proceeding is pending, may, before final judgment or after final judgment of discharge, or pending appeal, stay any proceeding against the person detained in any State court or under the authority of any State for any matter involved in the habeas corpus proceeding”.). See, e.g., United States $e x$ rel. Weisman v. Brown, 281 Fed. 657, 662 (Sth Cir. 1922).

20. 28 U.S.C. $\$ 2361$ (1948) (" . . the district court may . . . enter its order restraining ... [all claimants] from instituting or prosecuting any proceeding in any State or United States court affecting the property ... . involved in the interpleader action."). See e.g., Dugas v. American Surety Co., 300 U. S. 414 (1937).

21. See United States v. Sentinel Fire Insurance Co., 178 F. 2d 217, 232 (5th Cir. 1949) (dissenting opinion). 
an interpleaded party cannot be permitted to pursue an action against the interpleader in a state court. The other group of recognized exceptions comprises the Bankruptcy Act, ${ }^{22}$ the Limitation of Shipowners' Liability Act, ${ }^{23}$ the Frazier-Lemke Act, ${ }^{24}$ the Emergency Price Control Act, ${ }^{25}$ and the Public Utility Holding Company Act. ${ }^{26}$ Here Congress has granted the federal courts exclusive jurisdiction in order to secure efficient judicial administration of controversies which might otherwise be litigated in several courts simultaneously. In order to effectuate their exclusive jurisdiction, federal courts must have power to stay state court proceedings. Federal judicial disposition of a debtor's estate, for example, would lead only to confusing and interminable litigation if state courts were permitted to adjudicate claims against the same estate.

The exception for stays in aid of jurisdiction, however, requires neither express statutory authorization nor any specific type of litigation. It was designed to conform with the All Writs Statute authorizing issuance of any writ necessary to the jurisdiction of the federal court. ${ }^{27}$ Although the exception is used most frequently where a federal court has assumed jurisdiction over a res that later becomes the subject of a suit in a state court, ${ }^{28}$ it is not limited to that situation. If a federal court has assumed valid juris-

22. See, e.g., Bankruptcy Act of 1938, § 11a, 52 STAT. 849 (1938), 11 U.S.C. $\$ 29$ (a) (1946) (suit pending at time of filing of petition may be stayed until final adjudication); Eailey v. Blackmon, 14 F. 2d 16 (4th Cir. 1926). The numerous provisions of the Bankrupcy Act authorizing stays of state court proceedings are collected in Moore, ComrnenTARY ON THE U. S. Judicial Code 410 n. 60 (1949).

The Bankruptcy Act and most of the other statutory exceptions are collected in Toucey v. New York Life Insurance Co., supra note 15 , at 132-4.

23. 9 Stat. 636 (1851), as amended, 46 U.S.C. $\S 185$ (1946) (after deposit of security or transfer of interest to trustee, "all claims and proceedings against the owner . . . shall cease."). See The San Pedro, 223 U. S. 365 (1912).

24. 47 Stat. 1473 (1933), as amended, 11 U.S.C. $\$ 203$ (n) (o) (p) (1946). See Kalb v. Feuerstein, 308 U. S. 433 (1940) (statute ousted state court of jurisdiction in pending suit).

25. Emergency Price Control Act of 1942, § 204(d), 56 STAT. 32 (1942), 50 U.S.C. App. $\$ 924$ (d) (Supp. I, 1946) ; Bowles v. Willingham, 321 U. S. 503, 510 (1944) (since Congress granted to the Emergency Court of Appeals exclusive jurisdiction over attempts to contest the validity of the Act or orders under it, proceedings in state courts for that purpose could be restrained).

26. Public Utility Holding Company Act of 1935, $\$ 11(e), 49$ STAT. 822 (1935), 15 U. S. C. $\$ 79 k(e)(1946)$ (in order to carry out a reorganization plan the court may take exclusive jurisdiction of the company and its assets). See Okin v. SEC, 161 F. 2d 978 (2d Cir. 1947) (enjoining suit pending in state court).

For other statutes possibly falling within the Congressional authorization exception, see MOORE, op. cit. supra note 22 , at 410 . Stays under these statutes might also be justified as being in aid of the federal court's jurisdiction. Ibid.

27. 28 U.S.C. $\$ 1651$; see 28 U.S.C. $\$ 2283$, Reviser's Note (1948).

28. See MOonE, op. cit. supra note 22, at 411. 
diction and if, under the doctrine of comity, the circumstances are sufficiently extraordinary, interference with state proceedings is permissible. ${ }^{29}$

Under this exception, therefore, the third circuit could have correctly concluded that Section 2283 imposed no absolute bar against staying pending state criminal proceedings. But this does not mean that an injunction, or the court's substitute for an injunction, should have issued. The test should be the same as that governing issuance of injunctions against threatened prosecutions in state courts-that is, a clear showing of irreparable injury "both great and immediate." 30 While this does not call for invariable application

29. See, e.g., American Optometric Association v. Ritholz, 101 F. $2 \mathrm{~d} 883$ (7th Cir.) cert. denied, 307 U.S. 647 (1939) (enjoining vexatious and malicious civil proceedings pending in state courts). Although the case was decided under the predecessor of $\$ 2283$, it is applicable today, for $\$ 2283$ was intended to revive the state of law existing prior to Toucey v. New York Life Insurance Co., supra note 15. 28 U.S.C. \$ 2283, Reviser's Note (1948).

30. Spielman Motor Sales Co. v. Dodge, 295 U.S. 89, 95 (1935) (refusing to enjoin threatened prosecution under New York code of fair competition; no showing of irreparable injury; only a single prosecution contemplated).

The power of the federal courts to enjoin the enforcement of allegedly unconstitutional state criminal statutes, before any action is taken under them, has been clearly recognized since Ex parte Young, 209 U.S. 123 (1908) (enjoining institution of prosecutions to enforce confiscatory state rate-fixing statute; criminal penalties for violation so great as to deter testing validity of statute in state courts). Like Ex parte Young, supra, other early cases found irreparable injury if the threat of criminal penalties deterred plaintiff from following a course of action that might involve a violation of the statute. See Truax v. Raich, 239 U.S. 33 (1915) (where alien employee was discharged because employer feared criminal penalties for violation of statute forbidding employment of aliens, employee was properly granted injunction restraining enforcement of statute) ; Terrace v. Thompson, 263 U.S. 197 (1923) (where threatened prosecution under Anti-Alien Land Law deterred entering lease with alien, equitable relief was proper). But cf. Fenner v. Boykin, 271 U.S. 240 (1926) (participant in unlawful futures agreement was threatened with prosecution; injunction denied; plaintiff can assert defense of unconstitutionality in state court). For a recent case, see Stapleton v. Mitchell, 60 F. Supp. 51 (D. Kan. 1945), infra note 33 .

Showing a threat of multiplicity of criminal suits is the usuai way of satisfying the irreparable injury test. See, e.g., Cline v. Frink Dairy Co., 274 U.S. 445 (1927) (Colorado antitrust law held unconstitutional). Recent cases have required that there be a showing of the imminence of prosecution. See Watson v. Buck, 313 U.S. 387, 400 (1941) (injunction dissolved since no actual threats to enforce); Douglas v. Jeanette, 319 U.S. 157 (1943) (since the challenged statute was held unconstitutional in a companion case, the declared intention to institute other prosecutions did not constitute irreparable injury); cf. A. F. of L. v. Watson. 327 U.S. 582 (1946) (disruption of collective bargaining by threat of criminal sanctions against closed shop held irreparable injury warranting injunctive relief, decision on merits withheld pending state construction); and Stainback v. Mo Hock Ke Lok Po, 336 U.S. 368, 373 (1950) (injunction refused where enforcement by civil suit only), 28 Texas L. Rev. 410 (1950).

Some early cases drew a distinction between enjoining threatened prosecutions and staying pending ones. Cline v. Frink Dairy Co., supra, at 453 (enjoining all threatened prosecutions but refusing to stay pending proceeding although act was unconstitutional); see Ex parte Young, supra, at 162 . The distinction has not been mentioned recently and 
of the exhaustion of state remedies requirement, ${ }^{31}$ it does require that state remedies be inadequate to repair damage resulting from uncontitutional action. Under this test, federal intervention would be permissible only where the mere fact of actual or threatened prosecution causes the loss of substantial rights. For example, prosecution under an uncontitutional anti-picketing statute might deprive a union of bargaining power at an economically crucial time. Delay in adjudicating the constitutional issue would result in harm not reparable by later adjudication in the favor of the union. ${ }^{32}$ Similarly, multiple prosecutions brought for harassment purposes might cause irreparable harm even if charges were later dropped or convictions reversed. ${ }^{33}$

In the absence of such extraordinary circumstances, however, the constitutional question can as easily be decided in a state proceeding subject to review by the United States Supreme Court. ${ }^{34}$ This will almost always be true of

was probably overruled by implication in A. F. of L. v. Watson, supra. There the challenged Florida constitutional provision had not been construed by the state courts. Future prosecutions were enjoined, but at least some pending ones were allowed to continue in order to permit state construction of the provisions: "The resources of equity are not inadequate to deal with the problem [of restraining wholesale prosecutions] so as to avoid unnecessary friction with state policies, while selective cases go forward in the state courts for an orderly and expeditious adjudication of state law questions." 327 U.S. at 599 (emphasis added). Two implications seem justified: (1) if there had been no need for state construction, the district court could have stayed all actions, pending as well as threatened; and (2) the district court anyway had power to stay some of the pending prosecutions if circumstances warranted.

31. See cases cited in note 30 supra; cf. Lane v. Wilson, 307 U.S. 268, 274 (1939) (damage suit under Civil Rights Act; plaintiff held not required to pursue state judicial remedy before going into federal court).

32. International Longshoremens' \& Warehousemens' Union v. Ackerman, 82 F. Supp. 65 (D. Hawaii 1949) would seem to present such a situation. The district court enjoined multiple threatened prosecutions under the riot act as brought in bad faith as an attack on the labor movement and causing irreparable injury to collective bargaining. The court also stayed pending criminal proceedings for the same reasons, stating that $\$ 2283$ permitted the action as being in aid of its rightful jurisdiction. Id. at 107 . The ninth circuit, however, reversed, holding that the findings of bad faith and irreparable injury were not warranted. Ackerman v. International Longshoremens' \& Warehousemens' Union, 187 F. 2d 860 (9th Cir. 1951). The court also stated broadly that courts of equity could never enjoin pending criminal prosecutions. Id. at 868 . Cf. Stapleton v. Mitchell, 60 F. Supp. 51 (D. Kan.), appeal dismissed, 326 U.S. 690 (1945), enjoining enforcement of Kansas statute regulating labor unions as an unconstitutional restraint of free speech. Although no party to the suit had actually been charged with violation of the statute, the "pervasive threat inherent" in the very existence of the penal provisions generated fear so as to constitute a prior restraint on constitutional liberties. 60 F. Supp. at 61. Cf. Stainback v. Mo Hock Ke Lok Po, supra note 30 .

33. See International Longshoremen's \& Warehousemen's Union v. Ackerman, supra note 32; cf. American Optometric Association v. Ritholz, $101 \mathrm{~F} .2 \mathrm{~d} 883$ (7th Cir.), cert. denied, 307 U.S. 647 (1939), enjoining pending civil suits as "vexatious and malicious proceedings." Although the Rithola case involved private parties, its rationale would be just as applicable to criminal prosecutions. Furthermore, the court expressly held that former $\$ 379$ did not bar the injunction. Id. at 887 .

34. See, e.g., Fenner v. Boykin, supra note 30. 
procedural due process issues. A constitutional defect in the trial procedure is correctible through the state appellate system, on certiorari to the Supreme Court, and by habeas corpus. Any possible disadvantage ${ }^{35}$ which the accused might suffer by being forced to use these remedies can scarcely be classified as irreparable injury. ${ }^{36}$ Denying federal injunctive relief in procedural due process cases seems especially satisfactory when balanced against the expenditure of time and money for litigants and courts and the delay of speedy determination of guilt or innocence resulting from a federal injunctive proceeding. ${ }^{37}$

Thus, where the normal channels of protection are adequate, the doctrine of comity demands that they be used. This rule should not be circumvented by use of the Civil Rights Act to establish a system of interlocutory appeals to federal courts. The court in the Cooper case should have held that a denial of procedural due process could not be irreparable injury, and on that ground dismissed the complaint without ruling on the constitutional issue.

35. At worst the accused will be forced to undergo a retrial in order to secure an acquittal that would have resulted from correction of the constitutional error before conclusion of his first trial. If he is to be convicted anyway, the delay resulting from a reversal may simply give him more time of freedom. On the other hand, the accused might be acquitted in the first trial despite the constitutional defect. Furthermore, if there were other errors in the conduct of the trial, appeal and retrial would be necessary regardless of prior federal interference.

36. See Douglas v. Jeannette, 319 U. S. 157, 163 (1943). Another way of stating the irreparable injury test in the procedural due process area is in terms of "deprivation." Thus, a finding of unconstitutional deprivation at a preliminary stage of state proceedings is supportable only on the tenuous theory that the very process of being tried unfairly deprives an accused of rights protected by the constitution. Under this rationale, continuing the trial would further deprive and injure the accused. But if the due process clause gives an accused only the right not to be deprived of "life, liberty, or property," then there can be no deprivation by a state trial court ruling, short, at least, of an adverse judgment. U.S. Const. ANEND. XIV, $\$ 1$ ("nor shall any State deprive any person of life, liberty, or property, without due process of law ..."). Of course, if the argument were carried to its logical conclusion, there could be no deprivation short of-for example -imprisonment or execution. But as in the case of irreparable injury, at least a showing of imminence and immediacy should be required. This showing would seem highly unlikely before conviction. See Moore v. Dempsey, 261 U.S. 86, 90-1 (1922): "if in fact a trial is dominated by a mob so that there is an actual interference with the course of justice, there is a departure from due process of law; and ... 'if the State, supplying no corrective process, carries into execution a judgment of death or imprisonment based upon a verdict thus produced by mob domination, the State deprives an accused of his life or liberty without due process of law." "

37. For example, in the Cooper case the state trial was held up for over eight months. The complaint was filed in the district court on December 12, 1949. Joint Appendix, p. 1. The district court filed its opinion on January 27, 1950. Id., p. 2. The appeal was decided on July 21, 1950. Cooper v. Hutchinson, 184 F. 2d 119 (3d Cir. 1950). For the subsequent history of the case, see note 14 supra. See also Alesna v. Rice, 172 F. 2d 176, 177 (9th Cir. 1949) (declining to enjoin criminal contempt proceedings to enforce Hawaiian Territorial court order restraining mass picketing; the district court erred in ruling on the merits), commenting on the fact that the federal injunctive proceeding had delayed enforcement of the criminal law for 22 months, whereas available remedies in the Territorial courts could have disposed of the matter in three and a half months. 